PART 2

Identity and Citizenship 
Laurens Bakker - 9789004329669

Downloaded from Brill.come4/25/2023 11:58:23PM via free access 


\title{
Militias, Security and Citizenship in Indonesia
}

\author{
Laurens Bakker
}

The first of June is Indonesia's annual Pancasila Day. It is celebrated in commemoration of Soekarno's presentation on 1 June 1954 of Pancasila, the philosophical foundation of the unity of the Indonesian state, embodying ideals of its society and citizenry. 1 The day, generally, has dignitaries delivering speeches on the state of Indonesia and the nature of Pancasila. Speaking at a meeting at the People's Constitutive Assembly (MPR) on Pancasila Day 2012, VicePresident Boediono reminded his audience that, for the continued existence of Indonesia as a nation, creating unity in diversity and finding ways to live together harmoniously were crucial. Ethnic and religious differences should not stand in the way of Indonesian unity as exemplified, Boediono suggested, by the friendship of Soekarno - a Muslim - with Catholic priests during his exile in Flores in 1938. Religious fanaticism, Boediono warned, is a threat to the nation and to the peace of religious minorities (Aritonang, 1 and 2 June 2012).

Pancasila's emphasis on unity is Indonesia's ultimate ideological source of authority and, as such, is supposed to guide and pervade all legislation. In the preamble of the constitution, the elements of Pancasila are given as (1) belief in the one and only God, (2) a just and civilized humanity, (3) the unity of Indonesia, (4) democratic rule that is guided by the power of wisdom resulting from deliberation and representation and (5) social justice for all the people of Indonesia. ${ }^{2}$ These elements, clearly, have strong links to more well-known aspects of citizenship (such as protection by the state, a say in government and the sustaining relationship of community), but Pancasila is nevertheless hit by

1 This chapter is based on research conducted as part of the research project State of Anxiety: A Comparative Ethnography of Security Groups in Indonesia which was supported by the Netherlands Organisation for Scientific Research (grant number 463-08-003). Fieldwork and interviews were carried out between 2007 and 2013. Groups involved were Brigade Manguni, Komando Pertahanan Adat Dayak Kalimantan (KPADK, Dayak Customary Defence Command), Gerakan Pemuda Asli Kalimantan (GEPAK), Movement of Indigenous Youth of Kalimantan), Pemuda Pancasila, (Pancasila Youth) Garda Pemuda Nasional Demokrat (GP NasDem, National Democrats Youth Guard) and, to a lesser extent, Front Pembela Islam (Islamic Defenders Front) and Front Betawi Rempug (Betawi Brotherhood Front).

2 Based on a certified English translation available at the website of the Asian Human Rights Commission at http://www.humanrights.asia/countries/indonesia/countries/indonesia/ laws/uud1945_en. 
the persistent critique that its formulation is open to multiple interpretations and explanations along different political lines (see, for example, Wahyudi 2006). When Soekarno's successor, Suharto, imposed Pancasila as the nation's sole ideological basis, it was found that others were prevented from using the philosophy as an umbrella under which to maintain diverging ideologies (Ward 2010:30-31). This usage of Pancasila, therefore, served as a strong means to curb opposition, substantiate the regime's view on national and societal stability and legitimate control over the economy. These were then enforced by political, administrative and, where necessary, violent means.

The sudden end of Suharto's New Order regime in 1998, and the ensuing reformation politics, sparked a critical debate on the sources, applications and legitimations of public power. These debates centred on the (il)legitimate usage of government authority by state officials, and the state's weakness in upholding the rule of law in prosecuting abuses of government authority (Sakai 2002; Aspinalland Fealy 2003; Kingsbury and Aveling 2003; Schulte Nordholt and Van Klinken 2007; Aspinall and Mietzer 2010). A shared finding was the notion that there was little reason to assume that the weakening of the authoritarian central state would naturally result in democratic rule or increased civil awareness. In fact, factions of the regime, headed by powerful and wealthy individuals, managed to reorganize in the face of reform and continued their hold on economic and political influence (Robison and Hadiz 2004:18-252). Schulte Nordholt and Van Klinken (2007:24-25) referred to such regime patrons controlling the law and government agencies as a 'shadow state' of authority that exists beyond the institutions of government proper. The confrontation between these established power structures and the decentralization, democratization and advancement of civil society gave rise to a 'renegotiation of boundaries of authority' (Schulte Nordholt and Van Klinken 2007) between these established power holders and the new ones emerging as a result of democratic elections. This struggle, between patronage and clientelism on the one side and democratic reforms on the other, predates 1998. Almost from independence onwards, attempts to establish parliamentary democracy as Indonesia's system of government were seriously hampered by corruption, patrimonialism and client-patronage networks. Schulte Nordholt (2014) analyses this development using a longue durée perspective, which leads him to identify the current situation in Indonesia as a patronage democracy. Chandra (2004:6) defines this as a system 'in which the state has a relative monopoly on jobs and services, and in which elected officials enjoy significant discretion in the implementation of laws allocating the jobs and services at the disposal of the state'. Van Klinken (2009) and Aspinall (2013) note the manifestation of patronage democracy in different capacities - from the leaders who derive their power from the state 
while distributing clientelistic favours along economic, cultural and social lines, to the followers who identify themselves in local, ethnic or communal terms. Thus, a leader's authority is established by the democratic process and affirmed by their proven capacity to deliver.

An eye-catching element in the current phase of renegotiation is the increased social prominence of civil, militant organizations. These are organized, disciplined and uniformed bodies that generally represent specific religious or ethnic groups or are affiliated to political parties as dedicated security forces. They fall under the broad category of organisasi kemasyarakatan (societal organizations; abbreviated to ormas). ${ }^{3}$ Most of these organizations state their goals as specifically protecting the interests of the groups they represent, while simultaneously striving for a peaceful and united Indonesia. They generally proclaim Pancasila and the unity of the Indonesian state to govern their activities, thus nominally placing themselves within the ideological order of the state. ${ }^{4}$ Offering protection to the needy, ensuring peace and order, respecting the wishes of the local population and ousting bad influences are ormas activities that can be linked directly to the national philosophy. 'We work with all for the good of Indonesia and Pancasila, and strive to eradicate threats to the nation and the people,' Fary Malunda, a senior leader of the ormas Brigade Manguni told me, adding that Indonesia's famous diversity needs to be protected. While such statements could be seen as mere lip service to the national state and as 'cover-ups' of what amounts to the appropriation of state authority, it is very hard for such organizations to get anywhere without the support of the population, whose good Malunda proclaimed to have at heart.

In this chapter, I seek to come to terms with the role of ormas, particularly as forces that balance reactionary and pro-democracy interests as well as (often) furthering their own agendas. What is the role of ormas in the development of citizenship in Indonesia today? As will be made clear below, New Order-era

3 As a legal category ormas refers to all sorts of societal organizations: from aid foundations and health providers to Greenpeace and the World Wildlife Fund. Clearly, these are not intended here. The exact number of ormas is hard to establish. Nugroho (2013:16) found a staggering 83,727 civil society organizations registered with various ministries, but suspects that there is an overlap among those. Moreover, many of these groups will not be focused on security provision, nor will all security-providing groups have registered. Based on my own interviews with academics and government officials, estimates of 'security-providing ormas' in Indonesia range between 400 and 2,000 groups. These are spread throughout Indonesia but mostly active in urban areas.

4 A notable exception is Front Pembela Islam, whose drive to turn Indonesia into an Islamic state puts it at loggerheads with Pancasila's principles. FPI spokespersons have frequently expressed their discontent with the 'un-Islamic' Pancasila. 
history sees ormas as strongly associated with crime, lawlessness and patrimonialism, which would make them a disturbing and outright undesirable element in a democratic society governed by the rule of law. Increasingly, however, post-Suharto ormas - such as Brigade Manguni - maintain a strong focus on improving local welfare and aiding the community, which gains them popularity and credibility as socially engaged organizations willing to help the needy. On the other hand, as we shall see below, the criminal element has certainly not disappeared. One particular issue that will be scrutinized further is the crucial question: can crime actually serve the community?

The issue that I explore is the position of ormas in the relationship between the individual and the political community. This relationship, as argued in the introduction (Berenschot et al. 2017), is the central pillar of citizenship. It is shaped by 'particular conceptions and practices of rights, reciprocity and representation...' that '... are related to [postcolonial countries'] political economy and a particular history of state formation' (see also this volume's Introduction). As such, the daily practices of citizens' rights and duties in Indonesia have a history of personal relations at odds with the anonymity and accountability essential to Western ideals of state - citizen relations. In the following paragraphs, I discuss several examples of ormas' activities and strategies in order to come to an understanding of their functioning. I will explore their position in society - as serving patrons, or championing the masses - their effect in furthering or hampering the rights and duties of citizenship, and their recourse to violence and crime in doing so.

\section{Security versus Violence}

Most ormas manifest their power and obtain their support by providing security and protection in specific territories. On the street, they maintain a public presence through guard posts and patrols in 'their' neighbourhoods, for which the locals generally contribute a small monthly fee. They beat up and chase out thieves and burglars or, if they turn out to be locals, incorporate them into the organization - thus providing them with a job while enlisting their knowledge and muscle. Outside of the neighbourhoods ormas manifest themselves through rallies, parades or protests, the latter generally against 'bad' influences in public life. These can include media that published 'wrong' stories, politicians who are corrupt or take 'wrong' decisions, entrepreneurs competing with the ormas' supporters, or protesters, land occupiers or other critical voices that go against the interests or principles defended by the organizations. Some ormas, specifically Front Pembela Islam, also target artists whose music, 
performance or writings are 'disapproved of' by the organization. At times, this puts one ormas against another, both for ideological reasons (notwithstanding Pancasila) and in turf wars. ${ }^{5}$ Yet, within their areas, ormas usually undertake a wide range of security-providing activities and neighbourhood assistance, of which Table 6.1 gives an overview.

It is striking that, in most theories of state-building, the provision of security (as well as several of the other tasks listed above) are considered to be functions of the state. In carrying out these tasks, ormas thus display state-like qualities through their appropriation of the mutually constitutive processes of territorial control, authority and citizenship (Lund and Boone 2013:2). Ormas claim territory by providing security, and other services as listed in Table 6.1, to

TABLE 6.1 Overview of ormas community activities and services as observed and reported in Jakarta, East Kalimantan and the Minahasa

\begin{tabular}{|c|c|c|c|c|c|}
\hline & $\begin{array}{l}\text { Front } \\
\text { Betawi } \\
\text { Rempug }\end{array}$ & $\begin{array}{l}\text { Brigade } \\
\text { Manguni }\end{array}$ & $\begin{array}{l}\text { Front } \\
\text { Pembela } \\
\text { Islam }\end{array}$ & $\begin{array}{l}\text { Pemuda } \\
\text { Pancasila }\end{array}$ & GEPAK \\
\hline Guard posts and patrols & $\mathrm{X}$ & $\mathrm{X}$ & $\mathrm{X}$ & $\mathrm{X}$ & $\mathrm{X}$ \\
\hline Security firm for companies & $\mathrm{X}$ & $\mathrm{X}$ & & $\mathrm{X}$ & $\mathrm{X}$ \\
\hline Orphanages and schools & $\mathrm{X}$ & & $\mathrm{X}$ & & \\
\hline Financial aid to the poor & $\mathrm{X}$ & $\mathrm{X}$ & $\mathrm{X}$ & $\mathrm{X}$ & $\mathrm{X}$ \\
\hline Sport events & & $\mathrm{X}$ & & & \\
\hline Prayer meetings & $\mathrm{X}$ & $\mathrm{X}$ & $\mathrm{X}$ & & $\mathrm{X}$ \\
\hline Funeral assistance & & $\mathrm{X}$ & $\mathrm{X}$ & & $\mathrm{X}$ \\
\hline $\begin{array}{l}\text { Emergency relief (fires, } \\
\text { floods, mud slides, etc.) }\end{array}$ & $\mathrm{X}$ & $\mathrm{X}$ & $\mathrm{X}$ & $\mathrm{X}$ & $\mathrm{X}$ \\
\hline
\end{tabular}

5 Front Pembela Islam aims to defend Islam and Muslims against anti-Islamic dangers. The organization is known for smashing up bars and stores selling alcohol, destroying churches and for a drive to oust Ahmadiyahs from Indonesia, all of which it considers social vices. Ansor (in parts of Java) and Brigade Manguni (East Kalimantan and the Minahasa) actively work at keeping Front Pembela Islam out of their areas, as they regard the organization to be a vice in Indonesian society (personal communication by East Kalimantan's Brigade Manguni leader). An example of a turf war are the fights between Front Betawi Rempug and Pemuda Pancasila in Jakarta, which appeared to have gained impetus by the arrests of John Kei (in 2012) and Hercules (in 2013), both established Jakartan crime bosses, and the ensuing weakening of their respective gangs. 
its inhabitants and entrepreneurs. In exchange, they require monthly contributions from the households and businesses in the area. These contributions are generally fairly low, but monthly payments by several blocks of households provide substantial revenue for the ormas. ${ }^{6}$ Their regulatory activities provide ormas with influence in property transactions and in managing (new) entrepreneurs' access to the area. They can also arrange employment and practical training for those in need of it (motor mechanics, motor taxi drivers, shop staff, night watchmen, et cetera) and provide mass manpower when government, the neighbourhood, local entrepreneurs or others require it.

Usually, an area's inhabitants are reasonably positive about such local ormas activities. The presence of ormas guarantees less crime and assistance to the local poor in obtaining work and securing incomes. But this relation with members of ormas can turn sour quickly if the sales staff recommended by the local ormas head is not performing well and is fired. Likewise, a friend living in an upscale part of town in Samarinda (East Kalimantan) told me how the local ormas contacted him when he was extending his house and asked for an extra contribution of $10 \%$ of the building materials' costs. This was, as the ormas declared, because of the extra work the guarding of the building site would require. They settled on $5 \%$. When I asked him whether he felt cheated as he already paid monthly contributions, he replied that this was all part of democracy as the poor were just asking for a share of the wealth. Two days later, he asked passing ormas members to help shift a few stacks of roof tiles, to which they complied without fuss.

Ormas need local supporters in order to gain leverage with local power holders. Their position between the population and the established patrons means that they maintain their influence by engaging with and balancing the needs of both groups. For the common people in the cities and villages, ormas represent local and accessible providers of order and security, who, moreover, can communicate the peoples' needs to those in power, and, if necessary, put pressure on the local administration. For patrons, they are a source of votes, popular support and informal muscle. As such, ormas straddle the balance between democracy and patrimonialism by being accountable to their supporters on both sides for their activities and results. Failure to protect the needs of society

6 Protection fees in the upper middle-class Jakartan area of North Cikini, protected by the ethnic Betawi Forkabi ormas, stood at 50,00o rupiah per month per household in January 2014. Upon payment, which is generally made by the house staff as part of the monthly returning payments for electricity, laundry services and suchlike, Forkabi personnel provide a receipt stating that the contribution to neighbourhood security was paid for that month, as well as the name and signature of the collecting Forkabi member. 
will result in a loss of popular backing and greater dependency on patrons, thus severely limiting an ormas' credibility as a societal movement championing reform and democracy.

These two themes - reform and democracy - are essential elements in ormas' legitimization discourses. In a series of interviews I conducted, various ormas leaders and ormas lawyers explained to me that the provision of security, the monopoly on violence and the authority of the state should not be considered as exclusive domains of the government but rather as tasks with which the government is entrusted by society. If the government fails to do its job, it is up to society to step in and correct the faulty officials and that, these leaders maintained, is what ormas do. Lawyers connected to ormas emphasized that the Indonesian constitution allows Indonesia's citizens to do this (see Bakker 2015:88). It is in the latter framework that ormas spokespersons have presented themselves as the embodiment of the relationship between the political community and the individual. This relationship, defined by mutual rights and obligations - as argued in the Introduction - constitutes the central element of citizenship.

This position is perhaps best appreciated when considered through Abrams' (1988) distinction between the state as a system (the state's tangible institutions) and the state as an idea (that what is expected to make up the state). Ormas are not part of the official state system, which consists of the government apparatus and institutions. Yet, their capacity to act independent from government while legitimizing their actions through appeals to social circumstances, customs and religion, as well as the state, implies that the exercising of public authority in Indonesia is subject to a constant process of contestation and repositioning of institutions, in which new ones come to the fore as others lose influence and disappear (Olivier de Sardan 2005:16). Whereas Soekarno introduced Pancasila as a broad philosophy aimed at promoting national unity, Suharto's imposition of Pancasila as a national philosophy was used as a means to justify state control. Today, the national philosophy is therefore seen as a symbol of unity by some and detested as a means of repression by others. Balancing both democracy and patronage, ormas make use of such ambiguities in Indonesia's unity and reform to legitimize their own authority in guarding the interests of the population.

Herein lies their greatest challenge. Whereas the capacity for violence can be a means to provide security, it is also what security protects citizens from. Weber's observation - that the rise of European cities was closely connected to the combination of a marketplace and the presence of a self-equipped, armed citizenry capable of withstanding the overlord knights (Barbalet 2010:205-206) resonates in ormas' discourse of resisting the power of established elites in the 
name of the population. Yet how do the interests of the population and those of patrons balance out in ormas' provision of security to Indonesia's citizens at large? To answer this question, I will first address the ormas - patron relations from a socio-historical perspective in order to gain a better understanding of the established position of civil violence within the state. This is followed by a paragraph that considers ormas' functioning from the perspective of civil responsibility, public support and embedding in local society. I then continue to look specifically at the evolution of ormas in terms of societal and economic relevance for local society, before offering some concluding thoughts on how ormas' activities relate to citizenship in Indonesia.

\section{Return to Pancasila Day}

On the third of June 2012, a few blocks removed from the M PR Building, another Pancasila Day celebration took place at the National Monument (Monumen Nasional, or Monas). At the event, a two-hour mass rally was held by members and sympathizers of the National Democrat Party (Partai Nasional Demokrat). In his speech, party leader Surya Paloh, a business tycoon and national media owner, emphasized the need for change. He felt that any current social wrong was largely due to the fact that Pancasila was still not the basis of national life (Koran Bali Tribune, 4 June 2012). ${ }^{7}$ Watching the rally on television in a hotel room, I was struck by the large number of uniformed personnel that were present. Row upon row of people clad in black and dark blue uniforms stood to attention in disciplined ranks, their blue berets forming a colourful contrast against the dark background of the uniforms. In the wide-open space around Monas, they presented an image of massed ranks at the ready - to be deployed for a common goal. According to newspaper reports, 25,000 out of the 50,000 people attending belonged to the Garda Pemuda Nasional Demokrat (National Democrat Youth Guard, popularly known as GP NasDem), which was affiliated to the National Democrat Party. Members of the GP NasDem are young, as only the young have - according to the organization's website, that is - the drive and passion to change society. Therefore, the website reads, the young should be courageous and militant in striving for their goal, which is the restoration of the good elements from the past and the rekindling of the reform that started

7 Paloh emphasized the usage of Pancasila for the unity of the nation, as a moral code, as the main source of statehood and as a vision inspiring governance (see Aditya 2012:70-81 for a written-out speech of Paloh that addresses his thoughts on Pancasila along largely similar lines). 
upon the end of dictatorship, but that currently lacks direction and goals. ${ }^{8}$ The Garda's manifesto states that the organization is to be a vanguard for citizenbased democracy, and that its members should exert themselves to the utmost to seize the bright future of a welfare state - bringing liberty, solidarity and equality. ${ }^{9}$

A specific group within the GP NasDem is formed by its rapid reaction force (barisan reaksi cepat) known as BARET: a semi-military unit that can be deployed for the defence of the country and that has been trained by former military (Metrotvnews.com, 15 August 2013). In his Pancasila Day speech, Paloh described BARET's role as pioneers who lead the Indonesian people in guarding Pancasila and in putting a stop to the distortion and demoralization that engulfs the nation (Surya Paloh, cited in Media Indonesia, 4 June 2012). These goals appear fairly abstract, but are in line with the general ormas task of the provision of security. However, BARET members have also been trained in communicating the National Democrat Party's plans and visions. They carried out an ongoing grassroots campaign to mobilize support for the party in anticipation of the 2014 general elections. Furthermore, during the election period, BARET personnel were present at polling stations in order to observe the voting procedures (Metrotvnews.com 2013).

The notion of BARET carrying out a grassroots vote-mobilizing campaign and surveying at polling stations can be understood in two ways. First, one can see BARET as an instrument for intimidating voters on behalf of BARET's patron. Or as a civil organization that initially engages in vote mobilizing, but later moves on to survey procedures at polling stations. The latter task is a task carried out by numerous civil society organizations worldwide.

The image of the mass of ranked and uniformed people present at the National Democrat's Pancasila Day celebration, together with the speech that was delivered at that occasion, reminded me of Pemuda Pancasila (Pancasila Youth), possibly the best known ormas in Indonesia. Clad in distinctive brownorange camouflage uniforms, its members formed a highly visible element of many official occasions during the New Order. Officially, Pemuda Pancasila aims to defend Pancasila and to improve of the moral and economic welfare of marginalized youths, who otherwise eke out a living in the informal economy or in crime. Bringing these youngsters into the fold of the organization, Pemuda Pancasila argues, gives them a chance to better themselves morally

8 http://www.gardapemudanasdem.or.id/suara-muda/207-karakter-pemuda-pelopor-yang -progresif. Last accessed 7 July 2015.

9 See http://www.gardapemudanasdem.org/tentang-kami/manifesto. Last accessed 7 July 2015. 
and to improve their ties with nationalism (Ryter 1998:47). The organization thus combines a rank-and-file of urban poor and petty criminals with visible and moral adherence to the highest ideals of the nation (Ryter 1998:47). The result is a disciplined group of hardened muscle that is willing to act, violently if necessary, for the goals as expressed by the leaders of this ormas.

During the New Order, Pemuda Pancasila developed a working relation with Golkar, the then-dominant political party and Suharto's vehicle. The organization became the embodiment of Suharto's usage of Pancasila as a legitimization of state control. Opponents of the regime were threatened or attacked by Pemuda Pancasila members who were objecting to their 'anti-Pancasila attitude', or repeatedly harassed. Pemuda Pancasila members carried out their patrons' dirty handwork by beating up competitors or clearing inhabitants from new project sites through intimidation, violence and arson. The organization also provided security to businesses, upon the latter's request or forced, as a way of extortion. Members were engaged in theft, prostitution, drug trade and the protection of illegal bars and casinos, yet were largely above the law through their alliances the ruling elite. This relationship normalized Pemuda Pancasila's practices as violence and crime were associated with the regime (see Ryter 1998:48-53; Wilson 2006:266). As protesters marched the streets, calling for Suharto's resignation in 1998, Pemuda Pancasila organized counterdemonstrations and actively contributed to the chaotic violence in Jakarta that was intended to destabilize the capital and the opposition's support.

Pemuda Pancasila is, in the words of Ian Wilson (2010:199), the 'granddaddy' of organized preman groups. 'Preman' derived from the Dutch for 'free man', denotes gangsters or thugs, usually of the street-level variety, whose main modes of income generation are extortion, debt collecting, the vehicle-parking business and the provision of security to local shops and vendors. Indonesia has a history of organized territorial criminal groups (jawara) which are controlled by local strongmen (jago) who act as 'go-betweens' with non-criminal members of society (see Schulte Nordholt 1991). The New Order cracked down heavily on premanism through Pemuda Pancasila as well as through intimidation and the slaughter of thousands of preman by mysterious killers who turned out to be affiliated with the police and the military (see Van der Kroef 1985 and Barker 1998). The one way for preman gangs to operate safely was to ensure beking (backing) from among the higher circles of the regime particularly the police or the army. Patrons would protect 'their' preman in exchange for a percentage of its profits and physical assistance when needed. Such established groups, with Pemuda Pancasila as the best-known example, were both feared and respected in society. Virtually invulnerable to the legal system through their beking, occasional show trails would see preman leaders 
convicted to serving jail terms whenever the regime needed a sterner law and order image, but their sentences were usually drastically shortened as time progressed.

The nationwide mushrooming of security-providing ormas from 1998 onwards is shaped by this recent history. Political parties, with the regime's usage of preman for violent actions in mind, set up task forces (satuan tugas or satgas) such as the NasDem's BARET discussed above, that were charged with the provision of security and order at party events and for party members. Almost all militant ethnic and religious organizations that came into being throughout the nation declared that they were organizations aimed at protecting their supporters: from the greedy elites that had been plundering the country during the New Order, criminals, ethnic violence as well as religious fanatics. These groups were active under a wide variety of names which frequently contained martial terms such as laskar (army), brigade, front or komando, followed by a reference to a religion, an ethnic group, Pancasila or the Indonesian nation.

These ormas argue that they exist to provide the much-needed security to ward off the threat of other groups, which makes them reminiscent of the volunteer neighbourhood watches (ronda) and civilian security groups (such as linmas, hansip and satgas) that have existed in association with the government or the military for most of Indonesia's history as an independent state (see Barker 1999; Kristiansen and Trijono 2005:238-241). This argument also brings Indonesia's long war for independence to mind, which was waged against the Dutch colonial forces by numerous regional militias rather than by a nationwide Indonesian army. In fact, the idea that Indonesia's security is the domain of (local) society as much as of the state is an integral part of the nation's history. It has been made official through the national concepts of sishankamrata (total people's defence and security) and, more recently, sishanrata (universal people's defence), which propagates that the population should join the army, police and government with all possible means to defend the nation. The principle of local civilians who know each other and organize themselves in order to maintain security is thus an established practice ingrained in society as well as in the national defence strategy. The ready availability of trained civilians and the reform-driven withdrawal of military and police influence from civilian affairs makes security very much an issue of local concern. Siegel (1986), writing on the Javanese city of Solo, found that security rather than shared economic interests or kinship ties, was the most active expression of community in the cities' neighbourhoods. Moreover, as regional autonomy turned the region into the locus of political and economic identity, locals were presented with a scale of operation they could take up without government, state, patron, or regime assistance. 
In a 2005 interview, Barnabas Sebilang, then head of the Dayak Customary Council of Kalimantan (Dewan Adat Dayak seKalimantan) to which the Dayak Customary Defence Command (Komando Pertahanan Adat Dayak Kalimantan) serves as a security force, told me how local bands of fighters had fought against the Dutch colonial forces to liberate Indonesia, only to lose control over the development and governance of their areas once the nation was independent and its president established. That control needed to be taken back. Sebilang phrased it thus: 'We have been liberated from the Dutch, now we need to liberate ourselves from the control of Jakarta, from the Javanese.' Surprised, I asked him whether he intended for Kalimantan to become an independent state. He laughed, and told me that such a measure was not necessary at that moment, but that Javanese businessmen supported by the national bureaucracy were plundering the island's natural resources without regard for the national law. His organization was established to ensure that the new political climate would make it possible that Kalimantan's indigenous Dayak population would benefit from the island's resources. The actions of the Komando, he suggested, were nothing less than a fight for the liberation and emancipation of repressed citizens who needed protection of their rights as well as political guidance. This would be achieved by the proper implementation of Pancasila and the Indonesian constitution. Both of those legal sources, he felt, legally entitled the Komando to protect and enforce the rights of the province's Dayak population. I have discussed some of these actions by the Komando in other articles (see Bakker 2009, 2015). They involved issuing threats, applying violence, reclaiming land appropriated from local farmers by plantation companies, and the provision of security to the latter, many of which are, in fact, owned by Javanese businessmen.

Groups like the Komando Pertahanan Adat Dayak Kalimantan exist throughout Indonesia and combine a practical mix of relations to officialdom, a discursive emphasis on ethnic identity, the protection of local society and a dedication to the Indonesian nation with what their opponents claim is 'criminal activism' (such as illegal land re-appropriations). For such groups, societal support rather than patrons is the main source of beking. Massed members and supporters, whose opinions will translate into votes at the next elections, draw governmental attention and therefore affirm such organizations' relevance. The practice of violence, the level of criminality, the professed goals and the ideological underpinnings differ per group, but many groups appear to limit crime and violence as their following grows and become increasingly nonpreman and diverse. As Wilson (2010:201) points out: 'These organizations can simultaneously be violent defenders of reactionary and hegemonic interests and proactive vehicles for the social and cultural advancement of politically 
and socially marginalized communities' (italics in the original). The protection and provision of security to some, sustained by discourses of nationalism, civil rights and democracy, is combined with the threat of violence to others (see Bakker 2016). Popular opinion plays an important role in balancing protection and threat and, as we shall see below, is strongly influenced by the way in which ormas propose to put their muscle to the service of the public interest.

\section{Civil Responsibility, Violence and the Public Gaze}

As I was speaking to a group of Indonesian academics about the National Democrats' Pancasila Day rally a few days after it took place, several of them pointed out that my comparison to Pemuda Pancasila was not fair to the National Democrats' intentions. Surya Paloh, they felt, was one of the 'good guys' of contemporary Indonesian politics. As a long-term member of Golkar, Paloh ran for the position of party presidential candidate for the 2004 presidential elections but lost to New Order strongman army general Wiranto. Although part of the New Order establishment, Paloh was liked by the reformists: he had not been a member of the regime's in-crowd and was not associated with corruption, violence or similar vices. The social involvement of his National Democrat movement - not yet a party in 2004 - further indicated the difference between him and Golkar. In 2011, the National Democrat movement decided to form a political party in order to bring their aspirations into national politics, and Golkar asked Paloh to choose between them and the Democrats. Paloh left Golkar as he felt that the party's decreasing percentage of national votes indicated its failure to effectively engage with the desires of society (see Margianto 2011). In the running-up to the 2014 presidential elections, Paloh repeated his disappointment with Golkar, stating that the party lacked idealism, political rationality and common sense, whereas each cadre of the National Democrat Party was driven by his heart, morality and human compassion (Rosarians 2013). Many of the people with whom I spoke about Paloh positively emphasized his genuine concern, his clean past and his potential for bringing about change.

During interviews people also pointed out that although the BARET rapid reaction force was indeed useful to protect party rallies from attacks by thugs sent by Paloh's enemies, as a trained organization it left much to be desired. BARET could hardly be considered an ormas of Pemuda Pancasila standards, they felt. They had witnessed how the parade by members of BARET on the third of June had lacked in uniformity of movement and speed. This only showed, they argued, how difficult it is to discipline and train civilians. This 
did not, though, lead them to doubt Paloh's capacity for organizing defence and security. In the eighties, Paloh had been among the founders of FKPPI (Forum Komunikasi Putra-Putri Purnawirawan Indonesia, Communication Forum for Sons and Daughters of Retired Army Personnel), a preman organization closely connected to the military and committing extra-legal violence on its orders. From 1984 to 1987 , Paloh was chair of the advisory council, with Pemuda Pancasila leader Yapto Soerjosoemarno as its secretary. ${ }^{10}$ Paloh's past involvement with preman was seen as mostly irrelevant by his 2013 supporters since, as one person put it: 'that was in the past, when he was young. Others saw it as an asset, for the experience would surely have taught Paloh how to run a security force while at the same time being aware of the dangers an ormas could come to pose to ordinary citizens. Moreover, this aspect of his past was considered as proof that he was a 'tough guy' who would not hesitate to take action should the National Democrats' ideals or the security of Indonesia become in jeopardy.

Globe Asia (Zainuddin 2012:46) ranked Paloh as the one hundred and second richest Indonesian in 2012, with a net worth of 220 million Us dollars. As owner of the Media Indonesia Group and Metro TV, he has a substantial vehicle to spread the party's ideas and ambitions. Paloh's assets are his relatively new arrival on the political stage, his past involvement with a violent preman organization, his limited role in the New Order, his public distancing from Golkar and his passionate and socially driven speeches. He combines several of the characteristics that made New Order patrons liked and feared at the same time; Paloh is strong, powerful, not afraid to use violence and he passionately pleas for a more social and just Indonesian society. Also, his control over television channels assists him in getting his message across, although other parties - notably Golkar - have begun enlisting other media tycoons for the same purpose. ${ }^{11}$ The formation of BARET as a security force to the National

10 See FKPPI's website at http://www.fkppi.or.id/index.php/pengurus/fkppi/periode-ke-2. Last accessed 7 July 2015.

11 Golkar chairman Aburizal Bakrie owns station tv One through his Bakrie Group, while Chairul Tanjung, the owner of Trans TV and Trans7, is a close friend of incumbent president Susilo Bambang Yudhoyono, Hary Tanoesoedibjo, the owner of PT Rajawali Citra Televisi Indonesia, Indonesia's most popular television network, and PT MNC Skyvision, the country's largest pay-tv network, accepted a position as chairman of the board of experts of Paloh's National Democrat Party in 2012, but left again after a few months due to 'internal conflicts' (Sufa 2013) and moved to Golkar. With objective representation a rising concern (see Nazeer 2012), a parliamentary commission has started work on a draft amendment to the Broadcasting Law in order to severe political-media links ahead of the 2014 presidential elections (Jakarta Post 2013). 
Democrat Party appears to have been more of a side project - an element required to complete the full spectrum of forces a powerful leader should have at his disposal - than the creation of an organization aimed at violence and intimidation.

A rather different example of the effects of violence combined with a reputation for toughness is found in the development of Pemuda Pancasila's political aspirations. Following the fall of Suharto in 1998, this organization decided to end its collaboration with Golkar on the grounds that its support for the party did not result in appropriate returns. Pemuda Pancasila declared its own party, Partai Patriot Pancasila, on Pancasila Day 2001 and was registered in August 2003. The chair, Yapto Soerjosoemarno, explained that the cadre wanted to form an independent party to be able to benefit from its own supporters and their votes (see Dewanto 2003). They expected to gain many votes from young people who would be charmed by Pemuda Pancasila's toughness, while the inclusion of well-known singers and other artists on the candidate list would attract the workers and fishermen whom the party intended to target. The party secretary ventured the estimate that, with the votes of Pemuda Pancasila's large membership included, they would obtain $5 \%$ of the national vote (Liputan6.com 2004).

In the 2004 national elections, however, Partai Patriot Pancasila obtained 1,073,139 votes, or slightly below one percent, which meant that the party failed to gain any seats in parliament (Ananta et al., 2005:22). Partai Patriot Pancasila did not manage to convince its intended electorate, possibly because of decades of doing the 'dirty work' for the freshly removed New Order regime, and the strong competition presented by parties headed by known critics of Suharto and Golkar. Due to this election result, the party had to officially dissolve before registering again and, for the 2009 national elections, it registered as Partai Patriot, losing Pancasila, perhaps because public opinion had decidedly turned against the New Order usage of the concept. Nevertheless, these results were even worse: 547,351 votes or 0.53\% (Komisi Pemilihan Umum 2009:41).

Wilson (2010:209) wondered whether the low number of votes indicated that the party had made the same mistake that Pemuda Pancasila gave as its reason for leaving Golkar: failing to accommodate and articulate the aspirations of its supporters. Pemuda Pancasila members in East Kalimantan, who had not voted for Partai Patriot, suggested two further explanations to me. A first reason lay in the distinctive 'Jakartan' or 'Javanese' character of the candidates on the list, and a second in their desire to vote strategically rather than to support a small party that would almost certainly fail to obtain sufficient mass to become of national importance. Former or still serving Pemuda Pancasila members can be found throughout Indonesia's large parties and continue to 
take the organization's interest at heart. In a 2013 interview, former Pemuda Pancasila chair and current Golkar parliamentarian Yorrys Raweyai pointed out that, of the 560 Members of Parliament, about thirty were former Pemuda Pancasila members (Munawwaroh 2013a). Interestingly, Raweyai also stressed that he considered himself stigmatized by people calling him a preman, as he felt that he had never violated the law during his years in the organization (Munawwaroh 2013b).

Raweyai's notion of Pemuda Pancasila members as law-abiding, stigmatized citizens contrasts with the findings of a September 2013 report of a Pemuda Pancasila attack on a court of law dealing with a land dispute:

Hundreds of members of an organization notorious for its thuggery attacked the Depok District Court in West Java on Tuesday morning, threatening the chairman of the court over a disputed land case. Members of Pemuda Pancasila, dressed in the organization's military-style uniforms, rammed motorbikes into the court's glass entry door, smashing their way into the building as they headed to chairman Prim Haryadi's office. 'At about 8:30a.m., I was receiving some guests [in my office], when all of a sudden hundreds of PP members came breaking into the building with motorbikes,' Prim said later on Tuesday.

Upon noticing the chaos on CСTV, the judge immediately dismissed his guests just as dozens of angry PP members broke the door and windows in his office. The group reportedly launched a chair in Prim's direction in addition to threatening to kill him over a court decision to delay the execution of a previous verdict. "They just came in, more than 10 people were in my room wearing PP uniforms, including the leader, Rudi Samin, who refused to accept the court's decision to postpone a land eviction order. They threatened to kill me,' he said'.

JAKARTA GLOBE 2013

According to the article, the group came to the court house on behalf of Rudi Samin, the local Pemuda Pancasila leader, who had recently won a dispute over thirty-three hectares of land and had been informed by the court that the verdict would be executed on 17 September. Yet as the opposing party had filed an appeal, the court was held to stall the execution until after the appeal would be heard. In the attack on the seventeenth, the chairman of the court was forced to immediately sign the verdict, thereby allowing the eviction to commence. Rudi Samin confirmed the attack and took responsibility for the damage done to the building. Samin stated: 
'If the court would like to report us to the police, then go ahead. Pemuda Pancasila will take responsibility, he said. Explaining their motive behind the violence, Rudi said the attacks had been conducted to express their disappointment and distrust of the court. The PP would like to teach the district court a lesson. 'This is how you implement the law,' Rudi said.

JAKARTA GLOBE 2013

Samin, and two of his helpers, were arrested for vandalizing state property and transferred to regional police headquarters in Jakarta. As the case was examined further, various inconsistencies started to come to the fore. The first was that Samin was continuing legal procedures on behalf of other claimants who had never given him permission to act as their representative or put the claim in his name. The other claimants maintained that Samin owned about one and a half hectares of the contested land (which he inherited from his parents), and that the rest belonged to a group of some one and a half thousand other people (Virdhani 2013). The one reason they dared to speak up, a spokesperson stated, was because of Samin's removal by the police. Samin's urgency in getting the verdict executed, as a legal scholar following the case explained to me, was that the continuation of procedures would make both the appeal and the objections of the other claimants much harder for the judiciary to address.

Samin's detention was short-lived and does not appear to have resulted in further charges. In Depok's Pemuda Pancasila 2014 meeting, he emphasized that members should not fear arrest or, if they did, should not become Pemuda Pancasila members. Arrests are part of the process of Pemuda Pancasila activities, he felt, and he pointed out that he himself had been detained twice since he started his term as Depok's Pemuda Pancasila leader (Maulana 2014). At the time of writing, Samin was running in the 2014 general elections as a parliamentary candidate for the Indonesian Justice and Unity Party (PKPI), a split-off from Golkar which so far has failed to make the electoral threshold for national parliament.

Yet, in other contexts, Pemuda Pancasila is appreciated and liked by the population at large. A striking example is the discussion instigated by the 2012 movie The Act of Killing, directed by Joshua Oppenheimer, which sees aged Pemuda Pancasila members in Medan re-enact the killings of communists that were carried out in 1965 . Indonesian history depicts this killing of hundreds of thousands to millions of people nationwide as an act that saved the country from a communist coup, and declares those who carried them out as nationalists or even heroes. The film provides a much more critical picture and asks how the killings benefitted those in power, whether those killed were indeed guilty and who, in the end, actually profited from the killings. While the film 
provided intellectuals and activists with a platform to debate the killings as genocide and a human rights crime, others argue that the film is a foreignproduced narrative intended to tar Indonesia's reputation (e.g. Arham 2014) and presents a caricatured and one-sided view of events (Maullana 2014). The movie seems unlikely to bring about a new perspective on Pemuda Pancasila among the Indonesian population at large, and may even inadvertedly become a vehicle rallying support for the group's past acts.

Less bloody is the present day position of the organization in the East Kalimantese business town of Balikpapan. Here Pemuda Pancasila is headed by Syahrir Taher, a man in his sixties, who has been a Pemuda Pancasila member for decades. Locally, he is known as Pak Ketua ('Mr chairman') as he is the chairman of the local Pemuda Pancasila chapter, the chairman of the Partai Patriot faction in Balikpapan's parliament, and the chairman of Persiba, Balikpapan's football club. In a series of interviews in 2013, he told me how, in the fifties, his parents had migrated to Balikpapan from Makassar and brought him along as a little boy. He had little opportunity to go to school, but worked in the market and the harbour: first as a porter and wage labourer, and later as a provider of security. In that position, he had to fight and sometimes stab people, for which he went to jail a few times. He had no choice, he felt. He had agreed to guard his clients' properties, and had he run off, his reputation as a trustworthy guard would be gone. His violence and consequent prison sentences established his credentials as a tough guy who would not back down from his given word and was not afraid to draw blood or spill his own. There were other positives, too: he worked his way up from sleeping under market stalls to being able to buy his first house.

Contrary to Raweyai, Taher readily agreed that he is a preman and is happy to be known as such. As a member, and later a leader in Pemuda Pancasila, he put a lot of emphasis on helping his fellow members whenever needed. He was able to start a construction business, which flourished because of his ability to obtain government projects through his connections, and he became an affluent citizen. Taher used his funds to send his children to study overseas (religion in Bagdad before the invasion of Iraq and business studies in New Zealand afterwards), as well as for sponsoring Persiba, which, thanks to his support, sports at least three foreign players in the team each season. Taher is famous throughout East Kalimantan for his lavish handouts of food, favours and funds during the breaking of the fast each evening of Ramadan, at which time hundreds flock to his house, barring the traffic in the street (see Alamijaya 2013 for an on-site report). He takes great pride in helping anyone who requests his help and has a reputation for being generous. Yet, he is also known for asking people who request his assistance for a second time, what they have 
done to improve their position themselves. And this is, according to several market labourers with whom I discussed Taher's generosity, quite embarrassing. It makes people think twice before they knock again on Taher's door and ask for help.

Pemuda Pancasila and Taher are well established in the city. Taher maintains that the organization saved his life because he used to lack discipline when he joined. If Pemuda Pancasila had not taught him to think first and control his temper, he believes that he would have been long dead, stabbed or cut up by a rival in the protection business. Through his position in city parliament, Taher is involved in much of the city government's contracting, through which Pemuda Pancasila obtained numerous security contracts, including building projects, mining operations, employee housing areas, shopping centres and parts of the port. Pemuda Pancasila maintains a cordial relationship with East Kalimantan's police and army commanders, which ensures that major security deals are divided among these three groups.

As the chairman of soccer club Persiba, Taher is popular among Balikpapan's soccer enthusiasts. He arranges that the team gets good equipment, substantial sponsor deals and a steady stream of international players. In this position, he also holds an important role in the local election campaigns, as candidates vie for fifteen minutes of speaking time to address the audience ahead of a Persiba home match. Taher's control over this opportunity makes him highly influential in local politics.

Finally, Taher is a respected member of Balikpapan's Bugis community, after the Javanese the largest ethnic group of the city and one that is well-organized through the Kerukunan Keluarga Sulawesi Selatan (Harmonious Family of South Sulawesi, KKSS) - an organization that unites, connects and organizes the Bugis and Makassarese groups in the city. As Bugis are a major group of Pemuda Pancasila's members, there is a certain amount of overlap between the two organizations. In Balikpapan, Pemuda Pancasila have steadily retracted from the street work of security provision, rent-seeking and the parking business. Part of the more criminal elements of this business - gambling, prostitution, alcohol and drug smuggling - are now controlled by young preman who pay fees to Pemuda Pancasila through the Kkss (if they are Bugis) or other street groups. This way, Pemuda Pancasila is able to disassociate itself from criminal activities to a certain degree. But it is generally known that the organization does have considerable influence in the city and control over events, not in the least because of their links with preman.

An illustration of this control is the 2011 conflict over the Bugis ormas La Galigo. A group of Bugis, from within KKss and led by city parliamentarian Dahrimama, intended to set up their own ormas, which would go by the name 
of La Galigo, after the famous Buginese epic poem of that name. As preparations for the official procedure were under way, indigenous Dayak, Banjar, Kutai and other Kalimantese organizations called upon the city government to prohibit the establishment of the organization as it was foreign to Kalimantan soil and would no doubt lead to ethnic tensions. As both sides hardened their stances and pro and contra demonstrations were taking place, the police command decided to set up road blocks around city parliament and bring in extra squads of armed mobile police (brimob), which gave the usually peaceful city the look of a place awaiting invasion. After several days, in which leaders of both sides engaged in discussions with the police and city government, Pemuda Pancasila announced that they would not tolerate La Galigo, as they considered the organization disruptive to the peace of the city. The indigenous protesters were surprised and relieved, as they had expected Taher to side with his fellow Sulawesians. The La Galigo faction was disappointed, but took their loss as the Bugis in Pemuda Pancasila convinced the Kkss to end their support to the initiative. Very few media reported on the La Galigo issue and the ensuing tensions, and none mentioned Pemuda Pancasila or Taher, but as the police cleared away the road blocks, Pemuda Pancasila flags were flying from poles in the middle of the road in front of the city hall.

The actions by the groups discussed in this paragraph and the manner in which they present themselves indicate the importance attached to public opinion, albeit in a variety of ways. The docile attitude of the National Democrats' BARET is interpreted as proof of Surya Paloh's serious intentions. It is felt that he has a strong control over the organization. BARET is seen more as an aid organization which provides assistance in case of emergencies than as a band of thugs instrumental in building a shady protection-racket empire at the cost of the population. Many Indonesians I spoke to saw BARET as a 'good' ormas geared towards defending the peace and order within the nation. Moreover, they considered Paloh's ability to control BARET as proof of his suitability for the position of national leader.

The various examples drawn from Pemuda Pancasila's recent history show similar attention for the role of powerful individuals in society. Although the organization may have been unable to establish itself as a political party on the national level, its influence on the local level is not to be ignored. The aspects of the case of Rudi Samin in Bogor are striking. First, the fact that the media reports displayed shock over the attack on the district court, and that they offered considerable space to the villagers opposing Rudy's claim. Second, the proud and unrepentant attitude of Samin: the 'true mark of a real preman', a Balikpapan Pemuda Pancasila member assured me. 'He stands for what he believes is right. If he sees that justice is not being served by a court of law, that 
court needs to be taught a lesson.' This Pemuda Pancasila member felt that the outcome of the case was not necessarily bad for Samin: he might have had to spend some time in prison, but he had shown his dedication and toughness, thereby stressing his reputation as a powerful leader who is not afraid to act for cases he considers as good, regardless of the consequences.

Syahrir Taher in Balikpapan is an example of the type of 'self-made man' Rudi Samin likely aspires to become. Taher's own violent activities lie in the past and served him to steadily move into more respectable businesses. Making his fortune there, he has since added friendliness, helpfulness, piety and generosity to his reputation for toughness. As a result, he is widely liked and appreciated among the city's population. A Balikpapan lawyer who was a mutual acquaintance of Taher and me and present at my first meeting with Taher, told me afterwards:

He always explains his nickname of 'Pak Ketua' as referring to his various chairmanships, but that is not precisely what it means. What it means is that he is the chairman of Balikpapan. He runs everything; nothing big happens here if he does not support it. No business deals.... Candidates for the mayoralty are not accepted as candidates if he does not approve of them.

\section{A Need for Ormas? Brigade Manguni as a Case for Success}

Suharto's unexpected resignation in 1998 was accompanied by a number of local wars in various parts of Indonesia (see Van Klinken 2007). In 1999, fighting broke out between Christians and Muslims in the Moluccas. As the Muslim side began receiving support from the mainly Javanese Laskar Jihad militia, Christian refugees started to arrive in the Minahasa, the northernmost tip of Sulawesi and a predominantly Christian area. They brought with them news that Laskar Jihad fighters intended to follow the refugees into the Minahasa. A number of local militias were then set up to prepare for the defence of the area (see Jacobsen 2004; Henley, Schouten and Ulaen 2007). Among these was a group called Brigade Manguni; the name was taken from one of the fighter groups that held out the longest against the Indonesian army during the Permesta Rebellion of $1958-1961 .^{12}$ Like their illustrious predecessors they

12 Permesta was an uprising in parts of Sulawesi and Sumatra in the 1950s against Javanese domination of the governance of the Republic and Jakartan control over the development of these non-Javanese areas. 
prepared themselves through physical training and were taught indigenous magic by the tonaas, the leaders of the movement. These leaders also managed to obtain arms though contacts in government, the army and the police. Brigade Manguni's main leader was (and still is at the time of writing) Dicky Maengkom, a Manadonese who had returned a few years earlier from Jakarta where he had made a career as preman and entrepreneur. With the reputation, experience and contacts to form a militia, Maengkom set up a collaboration with the regional government, the church and local preman which resulted in a large, well-connected organization with a clear command structure and chapters throughout the area. Specific groups within Brigade Manguni received training from the military so that they could act as irregular auxiliaries to the army and police.

Laskar Jihad chose to travel to Poso in Central Sulawesi rather than to the Minahasa, probably because the Minahasan Muslims refused to side with Laskar Jihad and because a Muslim-Christian conflict was already brewing in Poso. In turn, Brigade Manguni also sent groups of fighters south, where they operated under the name of Kelalawar Hitam (black bats) because they were dressed fully in black and allegedly could fly noiselessly though the night using Minahasa magic. As national forces began to step in to bring the conflict to a close, Laskar Jihad and the Kelalawar Hitam left the area. Laskar Jihad was dissolved, while Kelalawar Hitam members retook their places as Brigade Manguni members and added considerably to the organization's prestige. With peace setting in in Sulawesi, Brigade Manguni began to place more emphasis on securing Minahasan society against more a variety of threats and providing a wider range of services. 'We are like Linmas (Lingkungan Masyarakat, a government service set up to respond to emergencies), only bigger and ready to deal with all kinds of danger. We can respond better', a Brigade Manguni tonaas explained. In practice, this means that Brigade members guard strategic public locations in the area during important occasions - such as elections, festive days, crisis meetings and so on. Also, they assist the government in case of natural disasters, such as volcanic eruptions or floods, by looking after their own members and their families. As with Pemuda Pancasila, Brigade Manguni recruited local heavies into the organization to secure the streets by employing them in their security business or the construction operations ran by its leadership..$^{13}$

The organization continues to emphasize its relevance by reacting to any potential threat to the integrity and peace of the Minahasa and its Christian

13 According to Maengkom, the Newmont Mining Corporation, which ran a gold mine in the Minahasa between 1993 and 2005, was one of their first major customers. 
inhabitants and by announcing mobilizations and preparing its fighters. Recent major cases include an attempt by Front Pembela Islam (the Islamic Defenders Front, a militant Islamic ormas) to open a chapter in the town of Bitung in 2009, and the 2013 invasion of the Malaysian state of Sabah by several hundred armed fighters from a militia who intended to claim the land for the former Philippine Sultanate of Sulu. Brigade Manguni used these occasions to emphasize the need for civilians to come to the aid of the army and police in guarding the Minahasa from outside threats. Thus, the organization regularly displays its level of organization and its potential for coordinated action. During official public occasions and national celebrations, the organization takes part in parades and provides honorary guards, therefore also emphasizing its connection to the state. Its leaders give speeches and muscled and tattooed members engage in displays of feats of invulnerability magic.

As Minahasans have migrated and settled throughout Indonesia, local chapters of Brigade Manguni have been established in locations like East Kalimantan, Jakarta, Bali and Makassar. These chapters are too small to pose competition to the local ormas, but the mother organization is respected and guarantees Brigade Manguni a (advisory) voice in local affairs of importance. More importantly, the Brigade Manguni network connects Minahasan politicians, entrepreneurs, professionals and heavies throughout Indonesia. Local chapters act as 'embassies', representing the Minahasan community at large and making sure that relevant information reaches interested parties. As such, Brigade Manguni has increasingly become a brokerage network connecting Minahasans throughout Indonesia as well as Minahasan and Indonesian businesses. It provides local knowledge, personnel, security or other services in every town or city where the organization is represented by a chapter. In 2010, Brigade Manguni was registered as a national organization by the Ministry of the Interior and, since then, this brokering of knowledge and business has increasingly expanded. This had brought the organization increasingly into contact with business people and politicians, and the leaders of the regional chapters are generally on good terms with the local power holders, and able to negotiate their interests through diplomacy rather than threats.

An example of this is the 2012 refusal of the population of Balikpapan to let Front Pembela Islam establish a chapter in this city. This, in itself, was an unlikely outcome because the majority of the city's population is Muslim and had no particular reason to object to the arrival of this ormas in their home town. The city has a minority Christian population which is mostly associated with indigenous groups. As they had just managed to prevent the large Bugis population - who are generally Muslim - from founding the La Galigo ormas in 2011 (see above), there was little reason to expect the Bugis to step out and 
join their adversaries in objecting to the arrival of Front Pembela Islam. However, they did so nevertheless - KKss representatives joined the protests and signed the petition asking city government to prevent the establishment of a Front Pembela Islam chapter in the city. When I spoke to the kKss regarding this choice, they told me that they had consulted with the head of the local Brigade Manguni chapter, with whom they maintain an 'all-Sulawesi' interest forum. The Brigade Manguni tonaas for East Kalimantan pointed out that those actively arguing for a Front Pembela Islam chapter were mostly Javanese, which would likely limit the chance of solid Sulawesi influence in the chapter. Also, he suggested, it was highly likely that Front Pembela Islam would upset the current power balance and instigate protests and riots to establish itself, which was bad for everybody's business. He also told the Kkss that the Christians who had objected to La Galigo were otherwise more than happy to work and live with the Bugis, and had no intention of further protests or violence. The possibility of Front Pembela Islam coming to the city had established ormas close ranks due to mediation of the local Brigade Manguni contingent, for which the latter duly took the credit.

Brigade Manguni evolved from a regional ormas established to protect the Minahasa against immediate threats into a nationwide network geared towards regional business opportunities and political influence. The Brigade still relies on popular support as well as on contacts with regional power holders, but its expansion into the national arena has made it into an organization for which trustworthiness has become more important and non-state violence less important. Its role as a social, unifying organization aimed at providing security for its members and the Minahasa does, however, remain crucial. In January 2014, parts of the Minahasa were hit by serious flooding. This caused the nearby East Kalimantan chapter to start sending over increasing amounts of goods, personnel and money to assist in disaster relief. The willingness to allocate considerable resources to such actions illustrates local chapters' willingness to operate beyond their local affairs and take the continued provision of Minahasans' security as a serious task.

\section{Conclusion}

Non-state provision of local security and defence of the state are inherent parts of Indonesian history and state - society relations. Armed civilians fought the Dutch for independence before the Indonesian army came into existence and continued to provide security among their local communities afterwards. Respondents cited above argued that once the values of Pancasila became 
known, these local groups accepted that philosophy and helped to establish the national state. But the New Order regime, they maintained, appropriated both ormas and Pancasila to serve its own needs. This caused public perceptions of both to deteriorate, but Reformasi would not have succeeded if new, local non-state security groups had not been mobilized to maintain order. While there are indeed examples of ormas stepping up in local social crises and calming matters down (see Bakker 2015), this 'local hero' image screens the fact that these ormas, rather than being passive guardians, are agents capable of generating considerable local influence. This influence is manifested in overt relations with politicians based on the support ormas can mobilize for their campaigns and elections, in the number and value of the project contracts that ormas leaders are able to obtain, and in the enlisting and subsequent employment of local preman muscle in security operations controlled by the organization. Importantly, however, an ormas' success depends on its appreciation by society. Without members and supporters to come out and back up the ormas in public, they will fail to impress anyone.

Ormas' provision of local security, considered a task of the state as the holder of the monopoly on legitimate violence in most theories of state-building, generates much support. However, their activities are also illustrative of an important aspect of citizen-state relations for, as civil society watchdogs and ormas alike point out, what guarantees the fairness and legitimacy of government institutions after so many examples of corruption, nepotism and other illegal actions damaging the interests of the population? As with Weber's observation, which notes that cities rose once they disposed of the soldiers to keep the overlord knights out of the cities' market places, ormas argue that they protect citizens' interests in the face of an elite that will not give up its New Order privileges. In other words, furthering the development of citizenship through active support of the needs and rights of the population is a route for ormas to ensure themselves of beking by society: a patron that cannot be voted out of office, but whose support ensures ormas' access to politicians and the economy.

Nevertheless, ormas remain popularly associated with criminal activities, a disregard for the law and a willingness to use violence. While this is a powerful and fear-inspiring image to capitalize upon, the application of violence and involvement in crime requires nuance and consideration if societal support is to be secured. Ormas' actions may involve violence and be illegal according to national law, but they will only negatively impact the ormas' reputation if a sizeable part of society perceives them as unjust or criminal. 'If we do not threaten to use violence, or actually use it every once in a while, we would be nothing but another NGO. Government does not listen to those organizations 
and the people do not know them', stressed Fary Malunda of Brigade Manguni. Yet, such violence and crime is subject to moral scrutiny. While few ormas supporters seem bothered by their defenders' involvement in such illegal activities as racketeering, gambling or prostitution, and even consider ormas' influence as proof of its power and authority, involvement in drug trade, kidnapping or contract murder meet with considerably less societal indifference. That is why most ormas deny any involvement in these criminal activities.

Ormas' activities as well as leadership are a mixture of populism, pragmatism and personal interests, and concern societal interests as well as reactionary patrimonialism. Leaders must seem strong, just, fearless and charismatic in order to be deemed capable. In this light, the action of Rudi Samin of Pemuda Pancasila, discussed above, makes sense: it is not just sheer brutality to ride a motorbike into the district court; it is a statement of courage and power which states that he is not going to back down when faced with what he perceives to be an injustice.

Ormas in Indonesia today exist by using a repertoire of citizens' rights and societal needs combined with the imagery and techniques that organizations like Pemuda Pancasila developed during the New Order. This image is powerful, but seems unable to survive the translation from the private loyalty of patronage to the public justification of one's actions required by democracy. Partai Patriot's political defeat and the steady decrease in prominence of political parties' security forces as violent actors, such as the National Democrats' BARET down-tuning to mere vote mobilizers, illustrate this. The practice of mobilizing societal support in order to put pressure on government signifies, to a certain extent, a reversal of patronage structures that confirms the rising influence of citizens aspired by democracy. As long as Indonesia's bureaucracy does not manage to inspire the sort of trust in government that will make support for ormas redundant, this combination of societal championing with elements of reform, patronage and crime creates a form of citizenship that emphasizes the position of the individual within the local community rather than within the nation.

\section{References}

Abrams, P. (1988). Notes on the difficulty of studying the state. Journal of Historical Sociology,,$(1)$, 58-89. doi: 10.1111/j.1467-6443.1988.tboooo4.x.

Aditya, W, (2012). Mari Bung Rebut Kembali! Surya Paloh [2010-2012]. Jakarta: MI Publishing. 
Alamijaya, J. (2013, 28 July). Ratusan Warga Tumpah Ruah di Acara Buka Puasa Syahril HM Taher. Tribunnews.com. http://www.tribunnews.com/regional/2013/o7/28/ ratusan-warga-tumpah-ruah-di-acara-buka-puasa-syahril-hm-taher.

Ananta, A., Ariffin, E.N., \& Suryadinata, L. (2005) Emerging Democracy in Indonesia. Singapore: Institute of Southeast Asian Studies.

Arham, F. (2014, 25 January). Film "The Act of Killing", Titik Nol, Sejarah SBY. www .kompasiana.com. Retrieved from http://www.kompasiana.com/prontzthetounz/ film-the-act-of-killing-titik-nol-sejarah-sby_5529850c6ea8347266552d15.

Aspinall, E. (2013). A Nation in Fragments. Patronage and Neoliberalism in Contemporary Indonesia. Critical Asian Studies 45 (1), 27-54. doi: 10.1080/14672715.2013.758820.

Aspinall, E., \& Fealy, G. (eds) (2003). Local Power and Politics in Indonesia. Decentralisation and Democratisation. Singapore: Institute of Southeast Asian Studies.

Aspinall, E., \& Mietzner, M. (eds) (2010). Problems of Democratisation in Indonesia. Elections, Institutions and Society. Singapore: Institute of Southeast Asian Studies.

Bakker, L. (2009). Adat, Land and Popular Democracy. Dayak politics in East Kalimantan. Borneo Research Bulletin 40, 202-220.

Bakker, L. (2015). Illegality for the General Good? Vigilantism and Social Responsibility in Contemporary Indonesia. Critique of Anthropology 35 (1), 78-93. doi: 10.1177/0308275X14557092.

Bakker, L. (2016). Organized violence and the state. Evolving vigilantism in Indonesia. Bijdragen tot de Taal-, Land-, en Volkenkunde. 172(2-3), 249-277.

Barbalet, J. (2010). Citizenship in Max Weber. Journal of Classical Sociology 10 (3), 201-216. doi: 10.1177/1468795X10371717.

Barker, J. (1998). State of Fear: Controlling the Criminal Contagion in Suharto's New Order' Indonesia 66, 7-42.

Barker, J. (1999). Surveillance and Territoriality in Bandung. In V.L. Rafael (ed.), Figures of Criminality in Indonesia, the Philippines and Colonial Vietnam. Ithaca (pp. 95-127). New York, NY: Cornell Southeast Asia Program.

Berenschot, W., Schulte Nordholt, H. \& Bakker, L. (2017) Citizenship and Democratization in Postcolonial Southeast Asia. In: W. Berenschot, H. Schulte Nordholt, \& L. Bakker (Eds.) Citizenship and Democratization in Southeast Asia (pp. 1-32). Leiden: Brill Publishers.

Chandra, K. (2004). Why ethnic parties succeed: patronage and ethnic head counts in India, Cambridge [etc.]: Cambridge University Press.

Dewanto, A. (2003, 1 August). Kecewa pada Golkar, Pemuda Pancasila Bikin Partai. Kompas. Retrieved from http://tempo.co.id/hg/nasional/2003/o8/o1/brk,20030801 -o6,id.html.

Jacobsen, M. (2004). Factionalism and secession in North Sulawesi Province, Indonesia. Asian Journal of Political Science 12 (1), 65-94. doi: 10.1080/02185370408434234. 
Jakarta Globe (2013, 18 September). Court Wilts Under Attack From Pemuda Pancasila Thugs. Jakarta Globe. Retrieved from http://jakartaglobe.beritasatu.com/news/ court-wilts-under-attack-from-pemuda-pancasila-thugs/.

Jakarta Post (2013, 25 September). Indonesian House Moves to Break Political-Media Links. Jakarta Post. Retrieved from http://www.nationmultimedia.com/aec/Indo nesian-House-moves-to-break-political-media-li-30215582.html.

Henley, D., Schouten, M., \& Ulaen, A. (2007). Preserving the peace in post-New Order Minahasa. In H. Schulte Nordholt \& G. van Klinken (eds.) Renegotiating Boundaries. Local politics in post-Suharto Indonesia (pp. 307-326). Leiden: KITLV Press.

Kingsbury, D. \& Aveling, H. (2003). Autonomy and Disintegration in Indonesia. London/ New York: RoutledgeCurzon.

Komisi Pemiluhan Umum (2009). Buku Saku Pemilu 20og. Jakarta: Komisi Pemiluhan Umum.

Kristiansen, S. \& Trijono, L. (2005) Authority and Law Enforcement: Local Government Reforms and Security Systems in Indonesia' Contemporary Southeast Asia 27 (2), $236-654$.

Liputan6.com (2004, 8 March). Partai Patriot Pancasila Menargetkan Lima Persen Suara. Liputan6.com. Retrieved from http://news.liputan6.com/read/73728/ partai-patriot-pancasila-menargetkan-lima-persen-suara.

Lund, C. \& Boone, C. (2013). Introduction: Land Politics in Africa - Constituting Authority over Territory, Propery and Persons. Africa 83 (1), 1-13. doi: http://dx.doi .org/10.1017/Sooo197201200068X.

Margianto, H. (2011, 7 September). Surya Paloh Mundur Dari Golkar. Kompas. Retrieved from http://nasional.kompas.com/read/2011/og/o7/14493094/Surya.Paloh. Mundur. dari.GolkarMedia Indonesia (2012). Nasional Demokrat Ajak Jaga Kemurnian Pancasila. 4 June.

Maulana, H. (2014, 5 March). Pemuda Pancasila Depok Gelar Raker Cabang ke-5. 5 March. Depoknews.com. Retrieved from http://www.depoknews.id/pemuda -pancasila-depok-gelar-raker-cabang-ke-5/.

Maullana, I. (2014, 18 February). "The Act of Killing" Masuk Oscar 2014, Jay Subiyakto Kecewa. Kompas. Retrieved from http://entertainment.kompas.com/ $\mathrm{read} / 2014 / 02 / 18 / 1238173 /$. The.Act.of.Killing.Masuk.Oscar.2014.Jay.Subiyakto .Kecewa.

Metrotvnews.com (2013, August 2013). NasDem Jatim Siapkan Barisan Reaksi Cepat. Metrotvnews.com. Retrieved from http://news.metrotvnews.com/read/2013/08/15/ 175152/NasDem-Jatim-Siapkan-Barisan-Reaksi-Cepat.

Munawwaroh (2013a, 17 March) Alumni Pemuda Pancasila Jadi Menteri dan Politikus. Tempo. Retrieved from http://metro.tempo.co/read/news/2013/03/17/064467526/ alumni-pemuda-pancasila-jadi-menteri-dan-politikus. 
Munawwaroh (2013b, 17 March) Yorrys Raweyai Tak Sungkan Disebut Mantan Preman. Tempo. Retrieved from http://metro.tempo.co/read/news/2013/03/17/064467507/ yorrys-raweyai-tak-sungkan-disebut-mantan-preman.

Nazeer, Z. (2012, 10 March). Indonesia's Political Media Masters. Jakarta Globe. Retrieved from http://jakartaglobe.beritasatu.com/archive/indonesias-political-media -masters/.

Nugroho, E. (2013). Bill on Societal Organizations (RUU Ormas) and Freedom of Association in Indonesia. International Journal of Not-for-Profit Law 15 (1), 13-37.

Olivier de Sardan, J.P. (2005). Anthropology and Development: Understanding Contemporary Social Change. London: Zed Books.

Robison, R. \& Hadiz, V. (2004) Reorganising Power in Indonesia. The Politics of Oligarchy in an Age of Markets. London and New York: RoutledgeCurzon.

Rosarians, F. (2013, 2 December) Ini Alasan Surya Paloh Hengkang Dari Golkar. Tempo. Retrieved from http://nasional.tempo.co/read/news/2013/12/02/078533852/ ini-alasan-surya-paloh-hengkang-dari-golkar.

Ryter, L. (1998). Pemuda Pancasila: The Last Loyalist Free Men of Suharto's Order? Indonesia 66, 44-73.

Sakai, M. (2002). Beyond Jakarta, Regional Autonomy and Local Societies in Indonesia. Adelaide: Crawford House Publishing.

Schulte Nordholt, H. (1991). The Jago in the Shadow: Crime and 'Order' in the Colonial State in Java. RIMA: Review of Indonesian and Malaysian Affairs: a semi-annual survey of political, economic, social and cultural aspects of Indonesia and Malaysia, 25(1), 74-91.

Schulte Nordholt, H. (2014). From contest state to Patronage democracy: The longue durée of clientelism in Indonesia. In D. Henley \& H. Schulte Nordholt (Eds.) Environment, Trade and Society in Southeast Asia. A Longue Durée Perspective (pp. 166-180). Leiden: Brill Publishers.

Schulte Nordholt, H. \& Van Klinken, G. (Eds.) (2007). Renegotiating Boundaries. Local Politics in Post-Suharto Indonesia. KILTV Publishers: Leiden.

Siegel, J. (1986). Solo in the New order. Language and Hierarchy in an Indonesian City. Princeton University Press: Princeton.

Sufa, I. (2013, 21 January) Harry Tanoe mundur dari NasDem. Tempo. Retrieved from http://nasional.tempo.co/read/news/2013/01/21/078455801/harry-tanoe-mundur -dari-nasdem.

Van Klinken, G. (2007). Communal violence and democratization in Indonesia; small town wars, London: Routledge.

Van Klinken, G. (2009) Patronage democracy in provincial Indonesia. In O. Törnquist, N. Webster \& K. Stokke (Eds.) Rethinking Popular Representation (pp. 141-159). Basingstoke: Palgrave Macmillan. 
Van der Kroef, J. (1985). Petrus: Patterns of Prophylactic Murder in Indonesia. Asian Survey $25,745^{-759}$.

Virdhani, M. (2013, 23 September) Perusakan PN Depok, Pepabri protes Rudi Samin Cs. Sinonews.com. Retrieved from http://metro.sindonews.com $/ \mathrm{read} / 786170 / 31 /$ perusakan-pn-depok-pepabri-protes-rudi-samin-cs-1379905599.

Wahyudi, A. (2006). Ideologi Pancasila: Doktrin yang Komprehensif atau Konsepsi Politis. Jurnal Filsafat 16 (1), 94-115.

Ward, K. (2010). Soeharto's Javanese Pancasila. In E. Aspinall, \& G. Fealy (Eds.) Soeharto's New Order and Its Legacy: Essays in Honour of Harold Crouch (pp. 27-38) Canberra: ANU E Press.

Wilson, I. (2006). Continuity and Change. The Changing Contours of Organized Violence in Post-New Order Indonesia. Critical Asian Studies 38(2): 265-297. doi: 10.1080/14672710600671244.

Wilson, I. (2010). The Rise and Fall of Political Gangsters in Indonesian Democracy. In: E. Aspinall \& M. Mietzner (Eds.), Problems of Democratisation in Indonesia. Elections, Institutions and Society (pp. 199-218). Institute of Southeast Asian Studies: Singapore.

Zainuddin, S. (2012). Masters of the universe. Globe Asia 6(6), 40-47. 